\title{
Differential targeting of immune-cells by Pixantrone in experimental myasthenia gravis
}

\author{
Roberta Marolda a, ${ }^{\text {, }}$, Chiara Ruocco ${ }^{\mathrm{a}, 1,2}$, Chiara Cordiglieri ${ }^{\mathrm{a}}$, Chiara Toscani ${ }^{\mathrm{a}}$, Carlo Antozzi ${ }^{\mathrm{b}}$, \\ Renato Mantegazza b , Fulvio Baggi a,* \\ a Preclinical Neuroimmunology Laboratory, Neurology IV, Neurological Institute “Carlo Besta”, Milan, Italy \\ ${ }^{\mathrm{b}}$ Neuroimmunology and Neuromuscular Diseases, Neurology IV, Neurological Institute "Carlo Besta", Milan, Italy
}

\section{A R T I C L E I N F O}

Article history:

Received 24 January 2013

Received in revised form 22 February 2013

Accepted 26 February 2013

\section{Keywords:}

Pixantrone

Acetylcholine receptor (AChR)

Experimental autoimmune myasthenia gravis (EAMG)

Immunomodulation

\begin{abstract}
A B S T R A C T
Pixantrone was shown to reduce the severity of clinical manifestation in experimental myasthenia gravis. In the present work we further studied its therapeutic effect. Our results demonstrate that a single administration suppressed AChR-specific immune-responses in primed rats. However, clinical symptoms could be improved only by repeated drug administrations (q7dx6 protocol- $8.12 \mathrm{mg} / \mathrm{kg}$ ); this treatment allowed stable serum drug levels for at least 7 days, as assessed by a functional T-cell bioassay. Pixantrone exerted strong in vitro inhibitory effect only on proliferating T-cells without impairing dendritic cell differentiation and B-cell viability. Our data further demonstrate that Pixantrone is a promising immunosuppressant drug that should be investigated in myasthenia gravis.
\end{abstract}

(C) 2013 Elsevier B.V. All rights reserved.

\section{Introduction}

MG is an antibody-mediated disorder in which autoantibodies against the acetylcholine receptors (AChR) activate the complement cascade leading to a numerical and functional loss of AChR at the neuromuscular junction (Fambrough et al., 1973; Heinemann et al., 1977; Kao and Drachman, 1977). As a consequence, neuromuscular transmission is impaired and patients complain of various degrees of muscle weakness and fatigability. Although the symptoms of MG are mediated primarily by autoantibodies, AChR-specific CD4 $+\mathrm{T}$ cells have a crucial role in the pathogenesis of the disease (Karachunski et al., 2000; Im et al., 2001). Indeed, effector Th1 cells secrete proinflammatory cytokines, such as IFN- $\gamma$, and are implicated in the pathogenesis of antibodymediated autoimmune diseases, since IgG synthesis is T-cell dependent (Romagnani, 1997; Weigle and Romball, 1997). The EAMG model, characterized by the presence of CD4 + T cells and autoantibodies (IgG1 and

Abbreviations: AChR, acetylcholine receptor; TAChR, Torpedo acetylcholine receptor; BZ, Bortezomib; $\alpha$-BTX, $\alpha$-bungarotoxin; Ct, cycle threshold; EAMG, experimental autoimmune myasthenia gravis; LNCs, lymph node cells; MTX, mitoxantrone; MG, myasthenia gravis; MMF, mycophenolate mofetil; MPCs, myeloid precursor cells; PIX, Pixantrone; p.i., post immunization; RIA, Radioimmunoprecipitation Assay; SPNCs, spleen cells; $\left[{ }^{3} \mathrm{H}\right] \mathrm{dT}$, $\left[{ }^{3} \mathrm{H}\right]$ Thymidine.

* Corresponding author at: Preclinical Neuroimmunology Laboratory, Neurology IV Unit, Neurological Institute “Carlo Besta”, Via Celoria 11-20133 Milan, Italy. Tel.: + 39 0223942255 ; fax: + 390270633874.

E-mail address: baggi@istituto-besta.it (F. Baggi).

1 Both authors contributed equally to this study.

2 Present address: Center for Study and Research on Obesity, Department of Medical Biotechnology and Translational Medicine, University of Milan, Milan, Italy.
2 types) specific for the AChR (Christadoss et al., 2000; Baggi et al., 2012), is considered a reliable model for the human disease and is suitable for investigating the pathophysiology of MG as well as novel therapeutic strategies (Souroujon et al., 2010).

New immunosuppressant drugs are under investigation in preclinical and clinical studies to assess their efficacy on autoimmune diseases. Mitoxantrone (MTX, a synthetic anthracenedione antineoplastic compound) has been approved by the FDA for use in multiple sclerosis (Gonsette, 2007; Conway and Cohen, 2010). MTX exerts multiple effects on the immune system: suppresses proliferation of T cells, B cells, and macrophages, and impairs antigen presentation by the induction of apoptosis in APCs; moreover, experimental studies showed that also B cell function, antibody production, and transcription of proinflammatory cytokines can be impaired. Nevertheless, MTX shows several side effects, most importantly cardiac dysfunction and altered values in left ventricular ejection fraction, with an increased risk with cumulative doses above $100 \mathrm{mg} / \mathrm{m}^{2}$ (Ghalie et al., 2002; Cohen and Mikol, 2004). Acute myeloid leukemia has been also reported (Martinelli et al., 2011).

Pixantrone (PIX) is a novel aza-anthracenedione molecule with antiblastic properties, developed to reduce the cardiotoxic effect of its analog MTX, and so far investigated only in the treatment of non-Hodgkin's lymphomas (Srokowski et al., 2011; Pettengell et al., 2012). The mechanism of action of PIX is largely unknown but is considered to be similar to that of MTX, since both drugs interact with DNA as intercalants and inhibitors of topoisomerase II (De Isabella et al., 1995).

The immunosuppressive effect of PIX has been previously investigated in EAE (Cavaletti et al., 2004; Mazzanti et al., 2005), and we 
have recently demonstrated the efficacy of PIX on EAMG $(16.24 \mathrm{mg} / \mathrm{kg}$, once a week for 3 weeks q7dx3, cumulative dosage of $48.72 \mathrm{mg} / \mathrm{kg}$ ) (Ubiali et al., 2008). Biological and immunological analyses confirmed that PIX reduced the severity of EAMG compared to vehicle-treated, as well as to MTX-treated EAMG rats (Ubiali et al., 2008). Therefore, the drug may have a potential role in MG treatment and hence its mechanism of action must be further investigated in EAMG in therapeutic regimens. In the current study we report new data on the efficacy of different therapeutic protocols in EAMG to identify the lowest PIX dosage still able to improve the clinical manifestation, and provide further evidences on the possible mechanisms associated to the immunosuppressive effect of this drug.

\section{Materials and methods}

\subsection{Drug}

Pixantrone (BBR2778) is an aza-anthracenedionic derivate developed by Cell Therapeutics, Inc. (Seattle, USA). Lyophilized PIX was reconstituted with sterile saline solution and added in vitro to cell cultures or administered i.v. in rats (Ubiali et al., 2008).

\subsection{Animals}

Female Lewis rats, 6-8 weeks old, were purchased from Charles River Breeding Laboratories (Calco, Italy) and kept at the animal facility of the Institute. This study has been approved by the Institute (code: IMP-03-11), and performed in accordance with the Principles of Laboratory Animal Care (European Communities Council Directive $86 / 609 / \mathrm{EEC}$ ). A total of 60 animals were used for all experiments and sacrificed after deep anesthesia via carbon dioxide; for immunization and treatments animals were anesthetized with $2 \%$ isoflurane (60:40 $\mathrm{N}_{2} \mathrm{O}: \mathrm{O}_{2}$, flow rate $0.8 \mathrm{l} / \mathrm{min}$ ).

\subsection{Antigens}

AChR was purified from Torpedo Californica electroplax tissue (Aquatic Research Consultants, USA) by affinity chromatography on Naja-naja siamensis (Sigma-Aldrich) toxin coupled to Sepharose 4B (Amersham Biosciences) and analyzed on SDS-PAGE (Aharonov et al., 1977). Peptide R97-116, corresponding to region 97-116 of the rat AChR $\alpha$-subunit, was synthesized by Dr. R. Longhi (C.N.R., Milan, Italy), as previously described (Baggi et al., 2004).

\subsection{Immunization and treatment protocols}

Three different single PIX dosages (4.06, 8.12, and $16.24 \mathrm{mg} / \mathrm{kg}$ ) were evaluated in rats primed with $50 \mu \mathrm{g}$ of Torpedo AChR (TAChR) in CFA. PIX was given $24 \mathrm{~h}$ after immunization and animals were sacrificed 10 days post immunization (p.i.). Lymph node cells (LNCs) were challenged in vitro with TAChR or ConA, as positive control. EAMG was induced by TAChR-immunization $(50 \mu \mathrm{g}$ TAChR in CFA); 4 weeks p.i., the animals $(n=40)$ were randomly assigned to the treatment groups described in the Results section. Treatments were performed via i.v. injections of PIX solutions or vehicle (sterile saline solution; $0.9 \% \mathrm{NaC} 1$ ). The potential toxicity of repetitive drug administrations was evaluated on healthy rats $(n=4$; protocol $16.24 \mathrm{mg} / \mathrm{kg}, \mathrm{q} 14 \mathrm{dx} 3)$.

\subsection{EAMG clinical evaluation}

Evaluation of disease manifestations in EAMG rats was performed by testing muscular weakness as reported (Nessi et al., 2010). Clinical scoring was based on the presence of tremor, hunched posture, muscle strength, and fatigability. Fatigability was assessed after exercise for $30 \mathrm{~s}$, using the grip strength test. Disease severity was graded as follows: grade 0 , normal strength and no abnormalities; grade 1 , mildly decreased activity and weak grip or cry; grade 2, clinical signs present before exercise (tremor, head down, hunched posture, weak grip); grade 3, severe clinical signs at rest, no grip, moribund; and grade 4, dead. Each animal was weighed and scored at the beginning of each experiment and twice weekly until the end of the experiment; EAMG was confirmed by Prostigmine test (i.p. injection).

\subsection{Evaluation of PIX level in serum}

Drug serum concentration was evaluated as previously reported (Cordiglieri et al., 2010). Briefly, healthy female rats were treated with one PIX i.v. injection $(4.06,8.12,16.24 \mathrm{mg} / \mathrm{kg}$ ) or PBS. Blood sampling was performed after $24 \mathrm{~h}$ and 7 days and sera were extracted. Sera were added, at different dilutions (1:10-1:100), to effector R97-116 specific T cells plated on CD3/CD28-coated 96-well plates for proliferation assays. In order to create a standard curve, R97-116 T cells were incubated with increasing amounts of PIX (1 pM-1 mM). After $72 \mathrm{~h},\left[{ }^{3} \mathrm{H}\right]$ Thymidine $\left(\left[{ }^{3} \mathrm{H}\right] \mathrm{dT}, 0.5 \mu \mathrm{Ci} /\right.$ well, PerkinElmer $)$ incorporation was measured and PIX concentrations in animal blood were evaluated comparing the counts of serum-treated and PIX-treated R97-116 T cells.

\subsection{Evaluation of anti rat-AChR antibody titre}

Anti-rat AChR Abs were assayed in individual sera by Radioimmunoprecipitation Assay (RIA) (Lindstrom et al., 1981). Rat AChR was extracted from HD rat muscle and labeled with $2 \mathrm{nM}\left[{ }^{125} \mathrm{I}\right]$ $\alpha$-bungarotoxin ( $\alpha$-BTX, PerkinElmer). Sera from PIX- and vehicletreated rats were incubated over-night with $\left[{ }^{125} \mathrm{I}\right]-\alpha \mathrm{BTX}$ labeled rat AChR ( $0.5 \mathrm{pmol})$. Ab-AChR complexes were precipitated by adding an excess of rabbit anti-rat IgG (Sigma-Aldrich). Immuno-precipitates were washed twice with cold PBS plus 0.5\% Triton X-100 (Carlo Erba) and $\left[{ }^{125} \mathrm{I}\right]-\alpha \mathrm{BTX}$ labeling was evaluated via a $\gamma$-counter (PerkinElmer).

\subsection{Real Time PCR}

Total RNA was extracted using Trizol reagent (Invitrogen).cDNA was synthesized from RNA using random hexamers (Applied Biosystems) and reverse transcriptase (Invitrogen). Real-time quantitative PCR for IFN- $\gamma$, IL-10, CCR-7, CTLA-4, FoxP3, IL-6, IL-12b and $\beta$-actin was performed using Assay-on Demand Gene Expression Products (Applied Biosystems). $\beta$-Actin was used as housekeeping gene. Real-time PCR reactions were performed in duplicates using an ABI Prism 7500 FAST Real-Time PCR System (Applied Biosystems). Levels of mRNA expression for each gene were calculated using the $2^{-\Delta \mathrm{Ct}}$ method, in which $\Delta \mathrm{Ct}$ represents the difference between cycle threshold $(\mathrm{Ct})$ of the target gene and $\mathrm{Ct}$ of the house-keeping gene.

\section{9. $R 97-116$ and OVA specific $T$ cell lines}

Female Lewis rats were immunized with $50 \mu \mathrm{g}$ of R97-116 or $50 \mu \mathrm{g}$ of OVA (Sigma-Aldrich) in CFA (Difco Laboratories). 10 days p.i. LNs were processed into a single cell suspension. LNCs were cultured in complete RPMI 1640 medium, containing 1\% Na-pyruvate, 1\% non-essential aa, 1\% L-glutamine, 1\% penicillin-streptomycin (Euroclone Celbio), and $50 \mu \mathrm{M}$ 2-mercaptoethanol (BDH), supplemented with 10\% FBS (Gibco), and stimulated with R97-116 or OVA $(5-10 \mu \mathrm{g} / \mathrm{ml})$. T cell lines were maintained by repeated stimulation with the appropriate antigen every 15 days, and expanded with IL-2 (10 U/ml; Peprotech) every 3-4 days thereafter. For proliferation assays, $3 \times 10^{4} \mathrm{~T}$ cells were co-cultured in triplicates with $2 \times 10^{5}$ irradiated (3000 cGy) spleen cells (SPNCs) per well in the presence of R97-116 or OVA in RPMI medium plus $2 \%$ normal rat serum. ConA (Sigma-Aldrich) was used as positive control. Increasing concentrations of PIX (range $0.1 \mathrm{pM}-10 \mu \mathrm{M}$ ) were added to each culture well. After $72 \mathrm{~h}\left[{ }^{3} \mathrm{H}\right] \mathrm{dT}$ was added to each 
well, later further $16 \mathrm{~h}$ cultures were harvested and counted on a Wallac MicroBeta TriLux counter (PerkinElmer).

\subsection{In vitro PIX treatment of immune cells}

LNs and SPN were removed from healthy and R97-116 and TAChRprimed rats after 10 p.i. and processed into single-cell suspensions; LNCs and SPNCs $\left(2 \times 10^{5} /\right.$ well $)$ were cultured with R97-116 or TAChR and ConA in RPMI medium with $2 \%$ normal rat serum. PBMCs were isolated from the blood of unrelated human donors by centrifugation over a density gradient (Ficoll-Paque ${ }^{\mathrm{TM}}$ Plus; Amersham Biosciences), re-suspended in complete RPMI 1640 medium plus 5\% human male serum type $\mathrm{AB}$ (Sigma-Aldrich) and plated $\left(2 \times 10^{5}\right.$ cells/well) with PHA $(10 \mu \mathrm{g} / \mathrm{ml}$ ). Increasing concentrations of PIX (range $0.1 \mathrm{pM}-$ $10 \mu \mathrm{M}$ ) were added to each culture well. After $72 \mathrm{~h},\left[{ }^{3} \mathrm{H}\right] \mathrm{dT}$ incorporation was evaluated. Informed consents for research use of biologic material were provided by all human donors.

\subsection{In vitro PIX treatment of myeloid precursor cells}

Myeloid precursor cells (MPCs) were prepared removing tibiae and femurs from healthy female Lewis rats, and BM were processed to single-cell suspensions. After osmotic lysis in erythrolysis buffer, BM cells were seeded $\left(1 \times 10^{6}\right.$ cells/ml $)$ in RPMI medium for $2 \mathrm{~h}, 37^{\circ} \mathrm{C}$, $5 \% \mathrm{CO}_{2}$. Non-adherent cells were removed and MPCs were cultured in RPMI medium plus 10\% FBS, GM-CSF and IL-4 (both at $5 \mathrm{ng} / \mathrm{ml}$, Peprotech) for 10 days to differentiate into immature DCs (iDCs). Fresh medium with GM-CSF and IL-4 was added after 3 and 7 days of culture. Cells were exposed to increasing concentrations of PIX (10 pM-10 nM) from day 0 to 3,0 to 7 and 3 to 10 . At the end of the experiment, cell viability was evaluated by immunofluorescence, using the greenfluorimetric Tunel reaction (DeadEnd Fluorimetric Tunel kit; Promega) labeling apoptotic nuclei, according to the manufacturer's protocol. Nuclei were counter-stained with DAPI (Chemicon). As myeloid lineage marker a mouse anti-rat OX82 primary Ab (Biolegend) was used, followed by Alexa-594 conjugated goat anti-mouse $\mathrm{Ab}$ (Molecular Probes-Invitrogen); mouse IgG1 (Biolegend) Ab was used as negative control. Images were captured using a confocal laser-scanning microscope (D-Eclipse C1; Nikon) equipped with $40 \times(\mathrm{NA}: 1.30)$ and $60 \times$ (NA:1.40) oil objectives. Image software was used for image analysis.

\subsection{Cytofluorimetry and cytotoxic assays}

MPCs from PIX-treated (one i.v. injection of PIX 4.06, 8.12, $16.24 \mathrm{mg} / \mathrm{kg}$ or 3 weekly PIX $16.24 \mathrm{mg} / \mathrm{kg}$ injections) or vehicletreated animals, were processed to single-cell suspensions and stained with mouse anti-rat OX82 (primary Ab followed by Alexa-488 conjugated goat anti-mouse $\mathrm{Ab}$ (Molecular Probes-Invitrogen)). As negative control, mouse IgG1 was used at the same concentration as the primary Ab. Cells were finally labeled with 7-AAD marker (BD) to visualize dead cells. B cells were purified from LNs and spleen of healthy rats by positive selection using FITC-conjugated anti-CD45RA Ab (OX33, Serotec) and anti-FITC magnetic MicroBeads (Miltenyi Biotec). Cells were cultured in RPMI medium with 10\% FBS for 3 days in the presence of PIX (10 pM-1 mM) and cell viability was evaluated using 7-AAD. All samples were acquired using a FACS vantage (BD) and gated for FSC and SSC parameters; the numbers of living and dead cells were counted relatively to a known amount of unlabeled beads appropriately gated (BD).

\subsection{Statistical analysis}

All values were expressed as means \pm SE. Statistical analysis of normally distributed data was performed using Student's $t$-test for two-group analysis; two way ANOVA was used for multiple group comparisons (GraphPad Prism, CA). Statistical significance was set at $\mathrm{p}<0.05$.

\section{Results}

\subsection{Improvement of EAMG by weekly administration of PIX $8.12 \mathrm{mg} / \mathrm{kg}$, q7dx6 protocol}

TAChR-immunized rats $(\mathrm{n}=16)$ were treated with PIX according to $\mathrm{T} 1$ protocol $(16.24 \mathrm{mg} / \mathrm{kg}, \mathrm{q} 14 \mathrm{dx} 3, \mathrm{n}=5)$ and $\mathrm{T} 2$ protocol (8.12 $\mathrm{mg} / \mathrm{kg}, \mathrm{q} 7 \mathrm{dx} 6, \mathrm{n}=5$ ), starting at disease onset (week $=4$; treatment schedules are reported in Fig. 1A); vehicle-treated EAMG rats (q7dx6, according to T2 protocol) served as controls $(n=6)$. EAMG clinical manifestations (body weight, Fig. 1B, and clinical score, Fig. 1C) were significantly ameliorated by both $\mathrm{T} 1$ and $\mathrm{T} 2$ protocols, compared to vehicle-treated animals; T2 protocol also determined a further improvement in EAMG clinical score compared to $\mathrm{T} 1$, starting at week 7 and becoming significant at week 9 (T2 = $0.29 \pm 0.27$ versus $\mathrm{T} 1=1.17 \pm 0.29$ mean clinical score $\pm \mathrm{SE}$, $\mathrm{p}<0.01$ ). Both T1 and T2 protocols correspond to a cumulative PIX dosage of $48.72 \mathrm{mg} / \mathrm{kg}$, as the one originally reported by us (Ubiali et al., 2008), but with a different schedule.

We then investigated whether a lower cumulative PIX dosage, (24.36 mg/kg, half of the initial value) could also modulate disease manifestation. Therefore, EAMG animals $(n=24)$ were treated according to T3 protocol $(4.06 \mathrm{mg} / \mathrm{kg}, \mathrm{q} 7 \mathrm{dx} 6, \mathrm{n}=6)$ and $\mathrm{T} 4$ protocol $(8.12 \mathrm{mg} / \mathrm{kg}, \mathrm{q} 14 \mathrm{dx} 3, \mathrm{n}=6)$; EAMG animals treated with T2 protocol $(n=6)$ and with vehicle $(n=6)$ were considered as controls. T3 and T4 treatments did not clinically improve EAMG, as demonstrated by body weight (Fig. 1D) and clinical score (Fig. 1E), not different from those of vehicle-treated EAMG animals.

In order to exclude overt side effects following PIX administration, we also treated healthy rats according to T1 protocol (HD/PIX, $\mathrm{n}=6$ ) and monitored body weight in comparison to vehicle-treated healthy rats (HD, $n=6$ ), assuming that a decrease of this parameter could be a possible PIX side-effect. Data indicated that PIX treatment did not induce body weight loss in HD/PIX compared to HD controls $(243 \pm 8.7$ versus $232 \pm 3.1$ mean $\mathrm{g} \pm \mathrm{SE})$.

In EAMG, anti-TAChR antibodies (of the IgG subtype) cross-react and recognize the rat (self) $A C h R$ located at the neuromuscular junction; hence, the level of anti-self AChR antibodies have been evaluated by the conventional Radioimmunoprecipitation Assay (RIA) in the sera of EAMG rats, collected at the end of the experiments (Fig. 1F). A significant decrease in the anti AChR-Abs titres was observed in T1-treated $(4.3 \pm 1.9$ mean $\mathrm{pmol} / \mathrm{ml} \pm \mathrm{SE})$ and in $\mathrm{T} 2$-treated $(13.7 \pm 8.2$ mean $\mathrm{pmol} / \mathrm{ml} \pm \mathrm{SE}$ ) animals, compared with vehicle-treated animals $(73.4 \pm 5.7$ mean $\mathrm{pmol} / \mathrm{ml} \pm \mathrm{SE}, \mathrm{p}<0.01)$, whereas animals treated according to T3 and T4 protocols showed high levels of anti AChR-Abs $(63.5 \pm 3.9$ and $53.6 \pm 8.7$ mean $\mathrm{pmol} / \mathrm{ml} \pm \mathrm{SE}$, respectively for $\mathrm{T} 3$ and T4), values comparable to vehicle-treated controls (Fig. 1F). The decrease in pathogenic Ab levels reflected the observed modulation of EAMG symptoms (Fig. 1B-E), proving the better efficacy of the PIX dosage of $8.12 \mathrm{mg} / \mathrm{kg}$ administered every week.

To better address the action mechanism of the drug in ameliorating the ongoing disease, the effects of the different PIX treatments were evaluated on mitogen- and antigen-specific responses of single cell suspensions from lymph node (LNCs). The yield of viable mononuclear LNCs was significantly reduced, independently from the PIX protocols given to EAMG animals (T1, 30.1 $\pm 10.4 \times 10^{6}$ cells; T2, $18.1 \pm 5.1 \times 10^{6}$ cells; T3, $17.5 \pm 7.7 \times 10^{6}$ cells; T4, $15.6 \pm 4.5 \times 10^{6}$ cells), compared to vehicle-treated EAMG rats $\left(147.3 \pm 25.8 \times 10^{6}\right.$ cells $)$ (Fig. $\left.1 G\right)$. LNCs recovery from popliteal and inguinal LNs isolated from naïve age-matched Lewis rats was $50.1 \pm 4.1 \times 10^{6}$ cells (Supplementary data, Fig. 1A, inset). A similar reduction was not observed in the number of viable cells recovered from the spleens of PIX-treated compared with EAMG animals (data not shown). 
A

TAChR/CFA

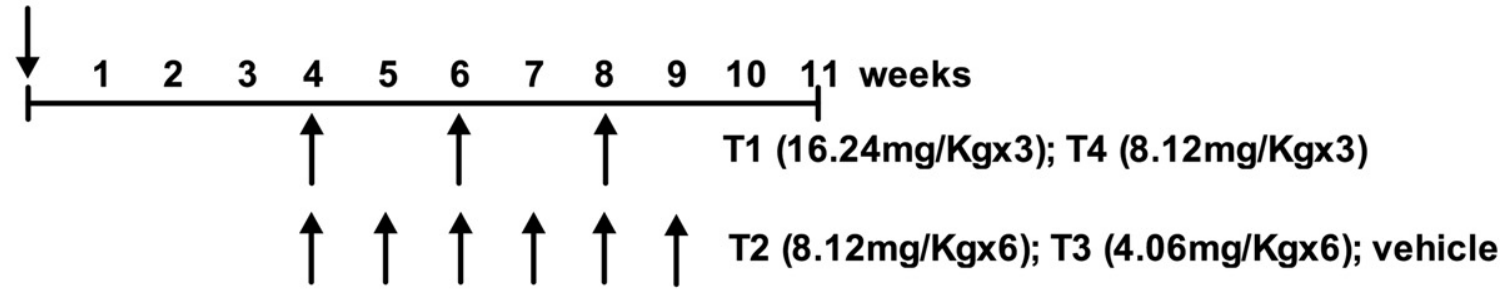

B

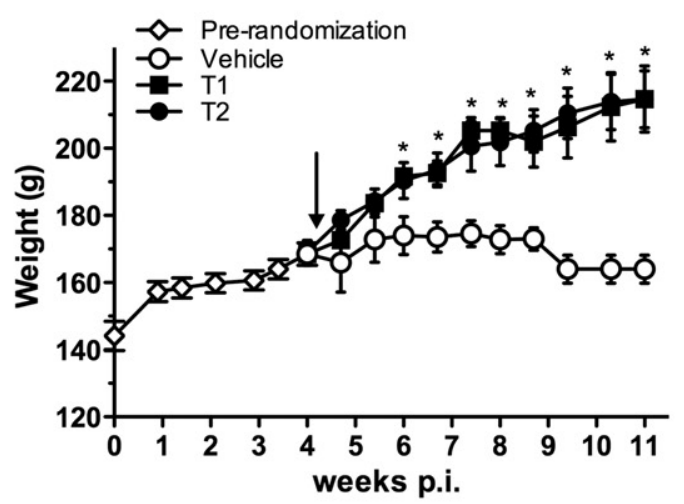

D

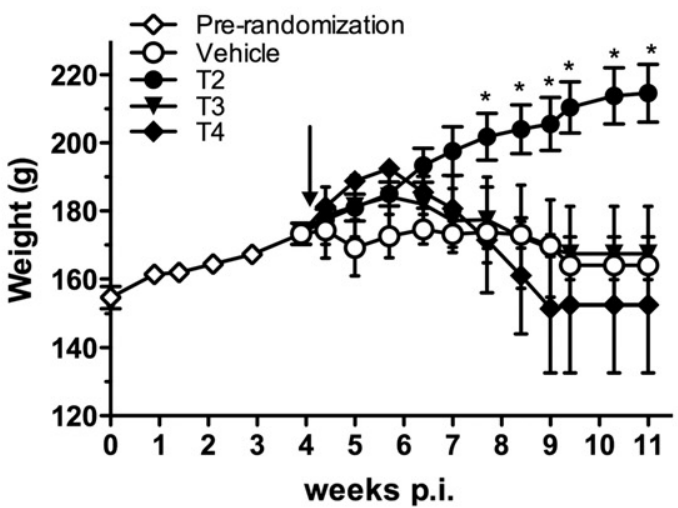

F

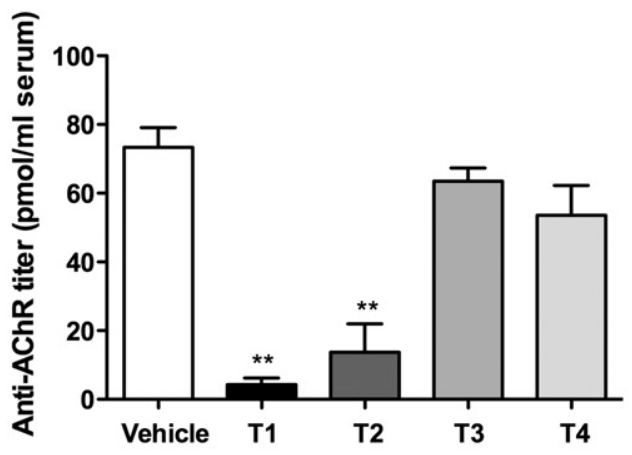

C

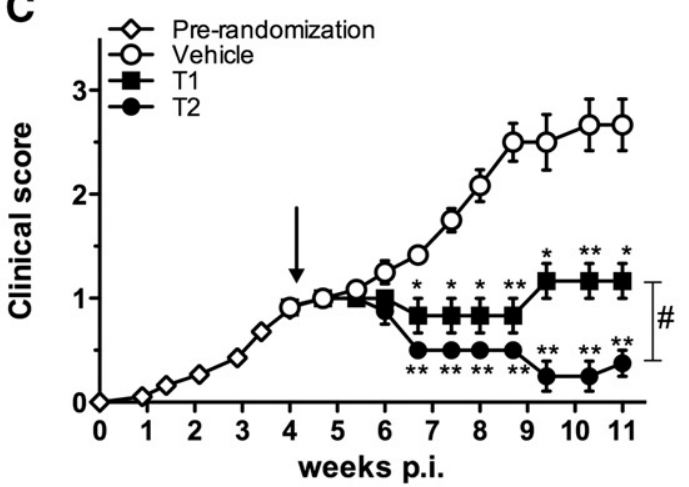

$\mathbf{E}$

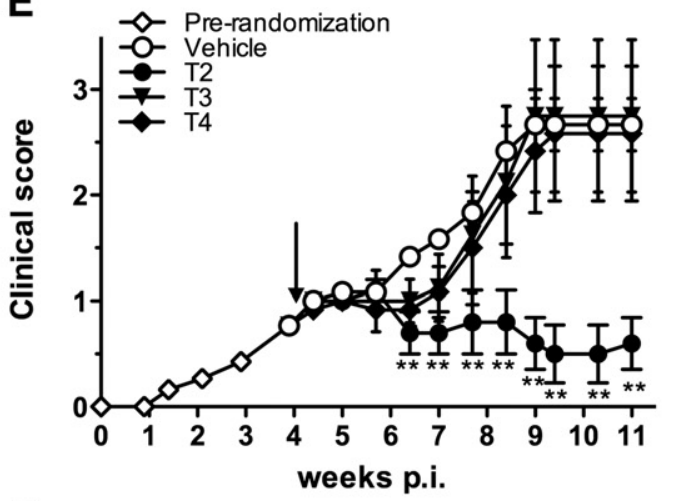

G

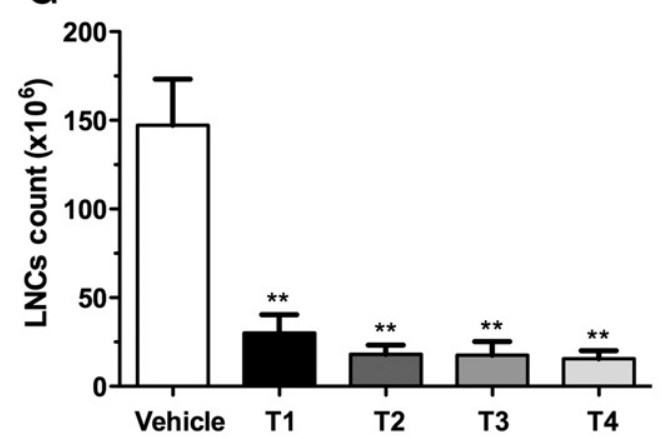

H

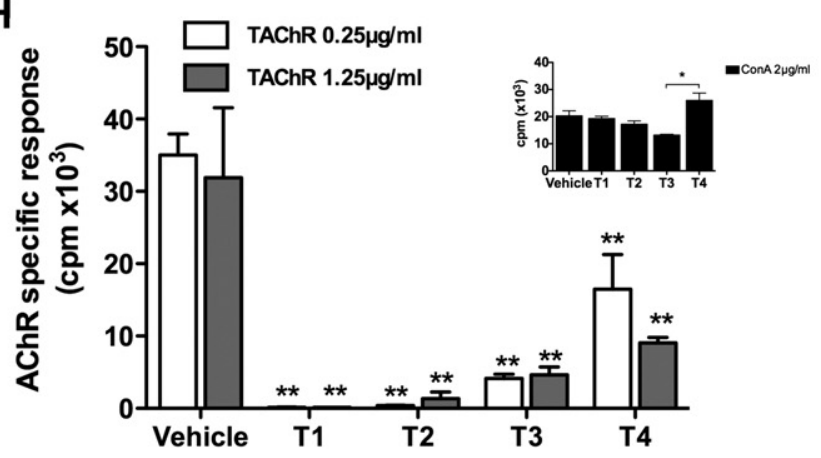


In vivo PIX treatments strongly affected TAChR-specific proliferative responses. Indeed, viable LNCs from experimental animals, stimulated ex vivo with TAChR, showed a significantly reduced proliferative response (Fig. 1H). Suppression of TAChR-specific response was almost complete in T1 and T2 treated EAMG animals: the observed residual proliferations were $0.5 \%$ ( $\mathrm{T} 1$ protocol, for both TAChR concentrations used in vitro) and $1.1-4.2 \%$ (T2 protocol, respectively for $0.25 \mu \mathrm{g} / \mathrm{ml}$ and $1.25 \mu \mathrm{g} / \mathrm{ml} \mathrm{TAChR}$ ) of the proliferative responses from vehicletreated EAMG animals. Although T3 and T4 protocols were not clinically effective, a significant reduction of TAChR specific responses was still observed (11.8\% and 14.6\% residual proliferation for T3 protocol; $47.1 \%$ and $28.3 \%$ residual proliferation for $\mathrm{T} 4$ protocol). On the contrary, ConA-induced LNC responses were moderately affected by PIX treatments (Fig. $1 \mathrm{H}$, inset). These results suggest that, at least in our experimental conditions, in vivo PIX treatments selectively inhibit only the antigen-specific $\mathrm{T}$ cell responses in LNs.

To further address this hypothesis, TAChR-primed animals received a single PIX administration $(4.06,8.12$, and $16.24 \mathrm{mg} / \mathrm{kg}$ ) or vehicle, $24 \mathrm{~h}$ after immunization ( $\mathrm{n}=16,4$ /group; Supplementary date, Fig. 1): all the three PIX dosages were able to significantly reduce the number of viable LNCs (panel A) as well as the proliferative responses to the priming antigen (TAChR) (panel B), but not ConA-responses (panel B, inset). The drug effect on LNCs was also studied even in naïve (healthy) rats, treated with PIX $16.24 \mathrm{mg} / \mathrm{kg}$ $(\mathrm{HD} / 16.24 \times 1, \mathrm{n}=4)$ or vehicle (HD/vehicle, $\mathrm{n}=4)$, without observing any difference in the viable LNC numbers (HD $50.1 \pm 4.1$; HD/PIX $44.5 \pm 2.1 \times 10^{6}$ cells, Supplementary data, Fig. 1A, inset), further confirming the immunomodulatory effect of PIX only on stimulated immunocompetent cells.

In order to gain further data on the possible effects induced by the in vivo PIX treatments in the EAMG model, we analyzed the expression levels of selected immune-related mRNA transcripts in animals treated with T2, T3 and T4 protocols. We focused our attention to the spleen cell (SPNC) population since it was not found affected by PIX treatments, as it occurred with LNCs. mRNA targets modulated by in vivo PIX treatments were IFN- $\gamma$ and IL-12b (Th1/Th17-type), IL-10 (Th2-type), CTLA4 (Treg-type), and IL-6 (Th3-type). Foxp3 (Treg-type) and CCR-7 did not show any differences (Supplementary data, Fig. 2).

\subsection{PIX bioavailability in the periphery}

EAMG course was significantly ameliorated by the T2 protocol, in which the drug has been administered i.v. at the dosage of $8.12 \mathrm{mg} / \mathrm{kg}$ for 6 times, every week. On the contrary, our data demonstrated the lack of efficacy when the same PIX dosage was administered according to T4 protocol (three administrations, every other week), or to T3 protocol ( $4.06 \mathrm{mg} / \mathrm{kg}$ for 6 times, every week). Hence, the level of bioactive PIX in the blood of PIX treated rats has been estimated using a functional bioassay in which animal's sera were tested for their capacity to inhibit $\mathrm{T}$ cell proliferation in vitro; the assay was adapted from Cordiglieri et al. (2010). Naïve animals received different doses of PIX (4.06, 8.12, and $16.24 \mathrm{mg} / \mathrm{kg}$, single administration), and serum samples were collected from the tail vein after $24 \mathrm{~h}$ and 7 days; the observed inhibition values (\%) of CD3/CD28 stimulated rat CD4 + T cells in the presence of serum samples have been plotted over a standard PIX dose-response inhibition curve, calculated for the same T cell line, in order to estimate PIX levels (Fig. 2). Sera from animals treated with
A

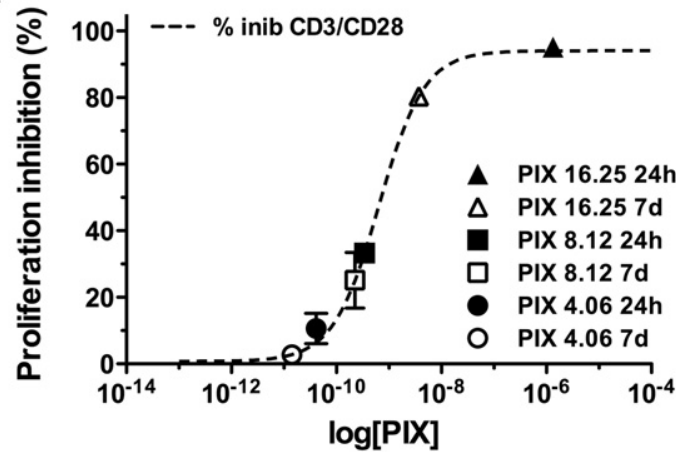

B

\begin{tabular}{lcc}
\hline $\begin{array}{c}\text { 24 h post } \\
\text { injection }\end{array}$ & $\begin{array}{c}\text { Serum-induced } \\
\text { proliferation } \\
\text { inhibition }\end{array}$ & $\begin{array}{c}\text { Relative PIX } \\
\text { concentration } \\
\text { in serum }\end{array}$ \\
\hline PIX 4.06 & $6.4 \%$ & $\log [\mathrm{PIX}]=-10.25=0.06 \mathrm{nM}$ \\
$\mathrm{PIX} 8.12$ & $33.3 \%$ & $\log [\mathrm{PIX}]=-9.55=0.30 \mathrm{nM}$ \\
$\mathrm{PIX} 16.25$ & $92.5 \%$ & $\log [\mathrm{PIX}]=-7.94=11.40 \mathrm{nM}$
\end{tabular}

\begin{tabular}{lcc}
\hline $\begin{array}{l}7 \text { d post } \\
\text { injection }\end{array}$ & $\begin{array}{c}\text { Serum-induced } \\
\text { proliferation } \\
\text { inhibition }\end{array}$ & $\begin{array}{c}\text { Relative PIX } \\
\text { concentration } \\
\text { in serum }\end{array}$ \\
\hline PIX 4.06 & $2.8 \%$ & $\log [\mathrm{PIX}]=-10.83=0.01 \mathrm{nM}$ \\
$\mathrm{PIX} 8.12$ & $25.1 \%$ & $\log [\mathrm{PIX}]=-9.68=0.20 \mathrm{nM}$ \\
$\mathrm{PIX} 16.25$ & $80.4 \%$ & $\log [\mathrm{PIX}]=-8.82=1.50 \mathrm{nM}$
\end{tabular}

Fig. 2. Evaluation of PIX concentration in serum. (A) Bioassay to determine PIX concentration within the serum of animals treated with one single dose of PIX (4.06, 8.12 or $16.24 \mathrm{mg} / \mathrm{kg}, \mathrm{n}=2 /$ group). The proliferation of R97-116 specific T cells was measured following $\alpha \mathrm{CD} 3 / \mathrm{CD} 28$ stimulation in presence of the indicated standard concentrations of PIX (range $0.1 \mathrm{pM}-1 \mu \mathrm{M}$ ), or in the presence of serum extracted from treated animals 24 h or 7 days after PIX i.v. injection. R97-116 T cell reactivity was evaluated by $\left[{ }^{3} \mathrm{H}\right] \mathrm{dT}$ incorporation 3 days after stimulation. Graph represents average data \pm SE from two independent experiments with triplicate measurements. Data are expressed as \% of proliferation inhibition. (B) The table shows relative PIX concentrations in serum, calculated from the values of serum-induced proliferation inhibition, as measured in (A).

PIX $8.12 \mathrm{mg} / \mathrm{kg}$ showed $33.3 \pm 1.5 \%$ and $25.1 \pm 4.5 \%$ inhibition (samples collected after $24 \mathrm{~h}$ and 7 days) of the CD4 $+\mathrm{T}$ cell line proliferation, corresponding to a serum PIX level of $0.3 \mathrm{nM}$ and $0.2 \mathrm{nM}$ respectively for the two time points; calculated serum PIX levels were: $11.4 \mathrm{nM}$ and $1.5 \mathrm{nM}$ (24 h and 7 days for $16.24 \mathrm{mg} / \mathrm{kg}$ in vivo dose), and $0.06 \mathrm{nM}$ and $0.01 \mathrm{nM}$ ( $24 \mathrm{~h}$ and 7 days, $4.06 \mathrm{mg} / \mathrm{kg}$ in vivo dose). These data suggest that a serum PIX level greater than $0.2 \mathrm{nM}$ should be maintained in vivo to suppress EAMG manifestations, as it occurs with the T2 but not T4 protocol.

\subsection{PIX inhibitory dose-response effect in T cell cultures}

To further elucidate the mechanisms of PIX-mediated immune suppression, we evaluated its in vitro effects on different $\mathrm{T}$ cell populations, exposed to PIX in the range of $0.1 \mathrm{pM}-1 \mu \mathrm{M}$. First, we used rat $\mathrm{CD}^{+}$ Th1 cell lines specific for the AChR-immunodominant peptide R97-116 (Fig. 3A) or for OVA (Fig. 3B), stimulated either with the

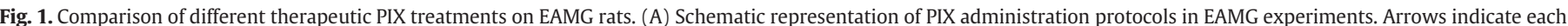

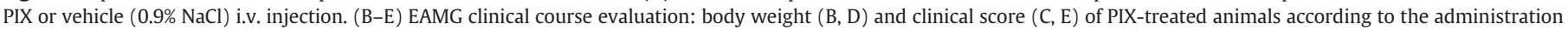

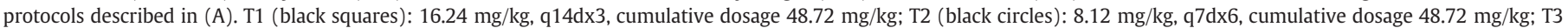

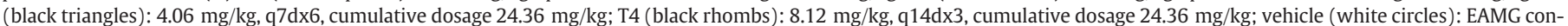

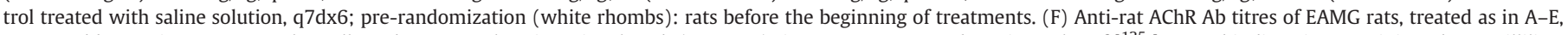

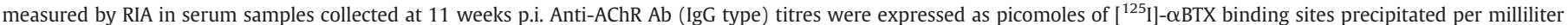

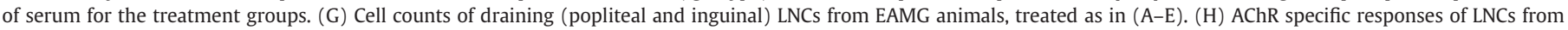

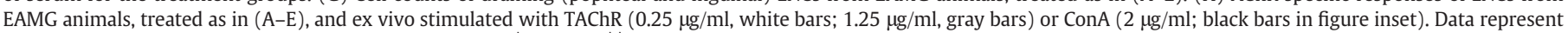
average \pm SE of two independent experiments. $\mathrm{p}$ values: ${ }^{*} \mathrm{p}<0.05,{ }^{* *} \mathrm{p}<0.01$ compared to vehicle and $\left({ }^{\#}\right), \mathrm{p}<0.01$ compared to T1. 
A

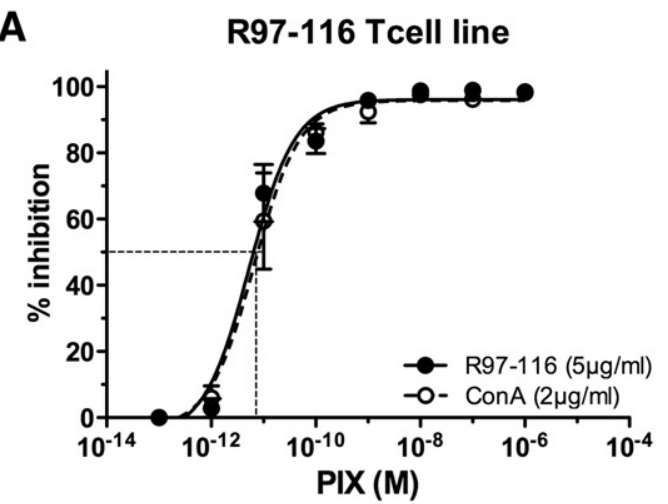

C

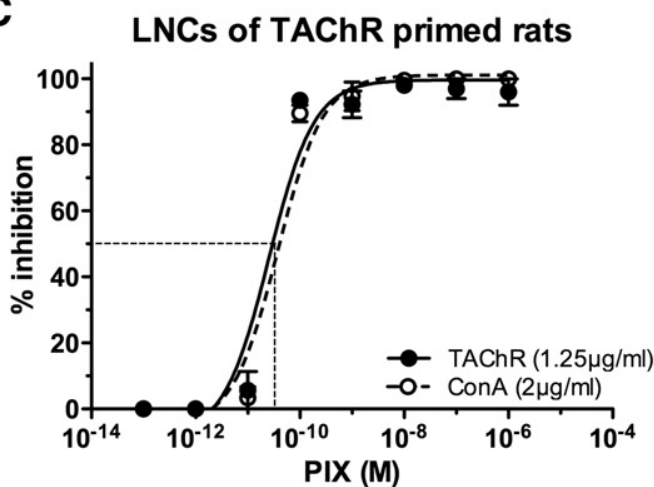

E

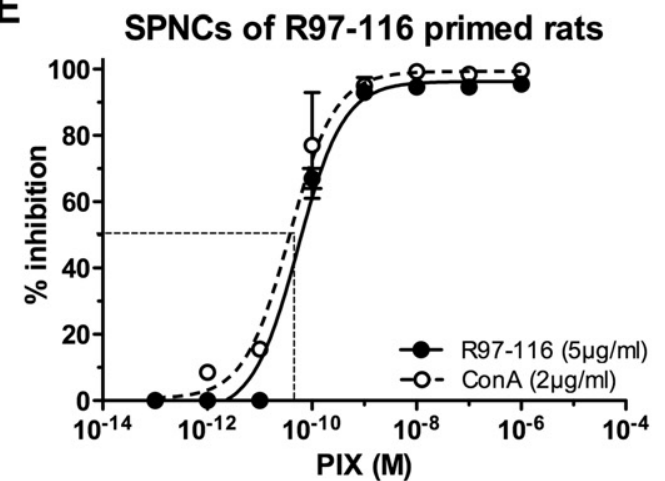

G

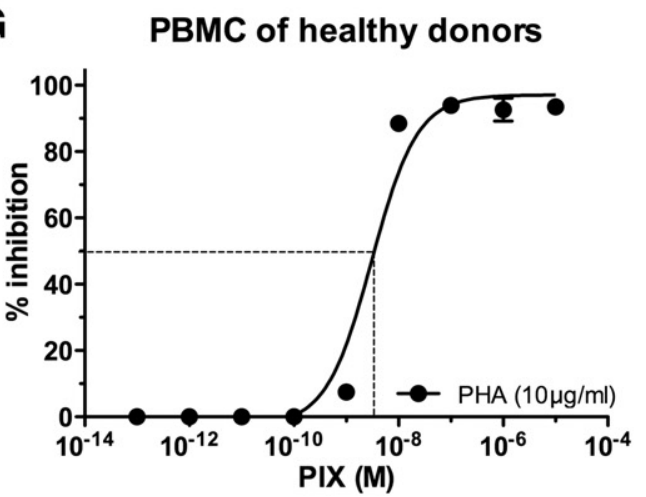

B

OVA Tcell line

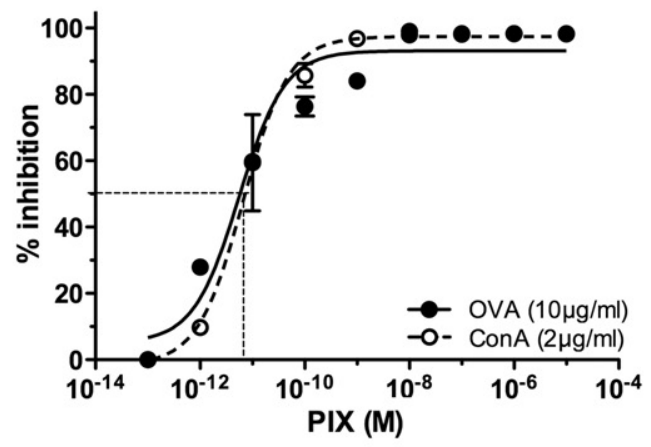

D

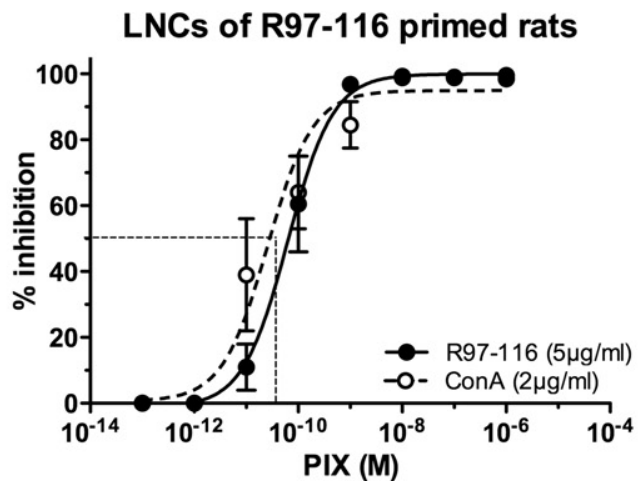

$\mathbf{F}$

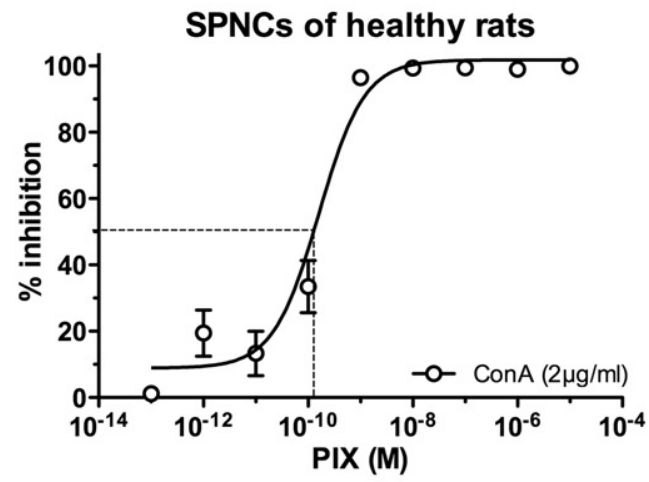

H

Maximal proliferative response to

\begin{tabular}{lcc}
\hline R97-116 Tcell line & $39808 \pm 8638$ & $43105 \pm 8606$ \\
OVA Tcell line & $50674 \pm 2170$ & $54013 \pm 1256$ \\
LNCs TAChR primed rats & $42686 \pm 9127$ & $30009 \pm 5939$ \\
LNCs R97-116 primed rats & $25801 \pm 3010$ & $14365 \pm 2962$ \\
SPNCs R97-116 primed rats & $14055 \pm 7313$ & $2376 \pm 1654$ \\
SPNCs healthy rats & $104623 \pm 9511$ & \\
PBMCs healthy donors & $39572 \pm 7578$ & \\
\hline
\end{tabular}

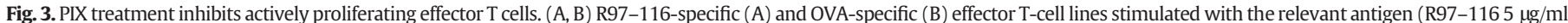

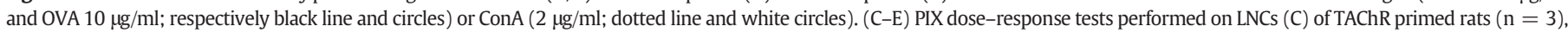

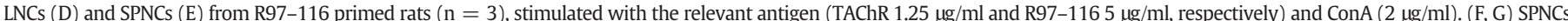

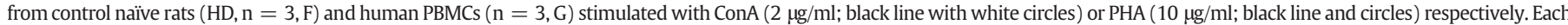

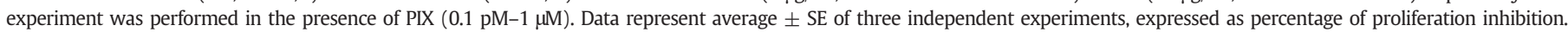

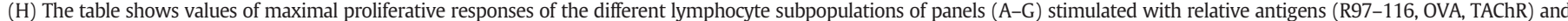
aspecific mitogens (ConA, PHA). Data resulting from three independent experiments expressed as mean cpm $\pm \mathrm{SE}$. 
relevant antigen or with ConA (aspecific mitogen), in the presence of PIX. The inhibitory dose-response curves were found to be similar for both $\mathrm{T}$ cell lines, with a calculated PIX IC50 (mean \pm SE) of $5.4 \pm$ $1.7 \mathrm{pM}$ (R97-116 response) and $6.7 \pm 1.6 \mathrm{pM}$ (ConA response) for R97-116 T cell line; $5.6 \pm 1.9 \mathrm{pM}$ (OVA response) and $6.7 \pm 2.0 \mathrm{pM}$ (ConA response) for OVA T cell line.

Next, we investigated PIX effect on mononuclear cell cultures from draining LNs and SPNs of TAChR or R97-116 primed animals, stimulated with the relevant antigen or with ConA, and exposed to increasing doses of PIX. Calculated PIX IC50 (mean \pm SE) for LNCs of TAChR-primed animals were $25 \pm 3.3 \mathrm{pM}$ (TAChR response) and $37 \pm 2.8 \mathrm{pM}$ (ConA response) (Fig. 3C). Similar values were obtained from R97-116 primed animals: PIX IC50 was $63.3 \pm 1.9$ pM (R97-116 response) and $25.7 \pm$ $3.0 \mathrm{pM}$ (ConA response) (Fig. 3D). PIX IC50 for SPNC cultures was $54.3 \pm 1.7 \mathrm{pM}$ (R97-116 response) and $37.4 \pm 1.7 \mathrm{pM}$ (ConA response) (Fig. 3E). Maximal proliferative responses in absence of PIX treatment are reported in Fig. $3 \mathrm{H}$.

Our data show that the amount of PIX required to exert inhibitory effect on LNC or SPNC cultures was 5-12 fold greater than that required to suppress responses of antigen specific T cell lines.

To complete our analysis, we evaluated PIX effect on SPNCs from naïve Lewis rats and on PBMCs from healthy human donors, stimulated with ConA and PHA, respectively (Fig. 3F-G). PIX IC50 (mean \pm SE) was $679.5 \pm 2.2 \mathrm{pM}$ (ConA-stimulated rat SPNCs) and $3362.0 \pm 3.4 \mathrm{pM}$ (PHA stimulated PBMCs). Again, a further increase in the PIX concentration is required by naïve rat SPNCs ( 100 fold), and even more by human PBMCs (1000 fold), as compared with those derived from antigen specific T cells.

\subsection{PIX inhibitory effect on culture and differentiation of myeloid precursor cells}

Because of the pivotal role of DCs in the antigen processing and presentation to T cells, we evaluated the effect of PIX on rat myeloid precursor cells (MPCs) derived from BM during the in vitro differentiation to iDCs. MPCs from naïve Lewis rats were treated with PIX $0.01 \mathrm{nM}$ (twice the IC50 value for T cells), $0.1,1$, and $10 \mathrm{nM}$, or normal culture medium, during the differentiation process into iDCs, and at different time points (Fig. 4A); cell viability was evaluated at the end of the differentiation period (day $=10$ ) by immunofluorescence (Tunel). iDC viability was not affected by PIX at $0.01,0.1$, and $1 \mathrm{nM}$ concentrations (Fig. 4B); a significant reduction in cell viability was observed when the differentiating MPCs were treated with the highest dose of PIX (10 nM), independently from the different exposure time (PIX-A, -B, $-C)$, leading to only $10-15 \%$ cell loss. These data indicate also that PIX is effective when given either in the first days of MPC differentiation (PIX-A, 0-3 days) or during the final maturation phase to iDCs (PIX-C) (Fig. 4B). Morphological analysis through confocal microscopy revealed a blockade of iDC differentiation, as highlighted by the generalized round shape of the cells and the absence of cellular extensions among MPCs treated with PIX $10 \mathrm{nM}$ (Fig. 4C); this was not observed during treatment with PIX $0.01 \mathrm{nM}$ (Fig. 4C), or with intermediate concentrations, conditions that, on the contrary, are effective in inhibiting $\mathrm{T}$ cell proliferation. The potential cytotoxicity of PIX was also evaluated on $\mathrm{OX}_{3}{ }^{+} \mathrm{B}$ cell, immunomagnetically selected from LNs and SPN of healthy rats. $\mathrm{OX}_{3} 3^{+}$was treated in vitro with PIX (range $0.1 \mathrm{pM}-$ $1 \mathrm{mM}$ ) for 3 days, and cell viability was measured via cytofluorimetry. Low doses of PIX (0.1 pM-10 nM) did not show any effect on the number of viable $\mathrm{OX}_{3} 3^{+}$cells, while $20 \%$ cell death was detectable only with 100 nM-1 mM PIX (Fig. 4D).

Moreover, the effect of in vivo PIX administration was evaluated on MPCs derived from BM of naïve animals (HD), to assess whether PIX induced a generalized myelotoxicity. Animals received a single PIX dose $(4.06,8.12,16.24 \mathrm{mg} / \mathrm{kg})$ or three PIX doses $(16.24 \mathrm{mg} / \mathrm{kg}$, every week), and the number of total MPCs and OX82 ${ }^{+}$MPCs was evaluated (Fig. 4E). We did not observe any difference among PIX- and vehicle-treated animals, independently from the PIX dosage. The cytofluorimetric data were confirmed by Trypan blue viability assay (data not shown).

Hence, low PIX levels are effective in blocking effector T cell activation and proliferation (Fig. 3 and Supplementary data, Fig. 1), without affecting myeloid cells and B cells, at least in our experimental conditions (Fig. 4).

\section{Discussion}

Therapeutic options for MG include corticosteroids and immunosuppressive drugs, pharmacological agents exerting a nonspecific generalized immune dysfunction (Conti-Fine et al., 2006). Although these treatments are effective in a large proportion of patients, in some cases the clinical response is unsatisfactory, or the severity of side effects may represent a limiting factor to their prolonged administration (Kumar and Kaminski, 2011). In this regard, new potent but welltolerated immunosuppressive drugs are needed for treatmentresistant MG (Mantegazza et al., 2011; Cavalcante et al., 2012). MTX, a synthetic anthracenedione antineoplastic compound, has been approved by FDA for the treatment of progressive multiple sclerosis (Gonsette, 2007; Conway and Cohen, 2010). However, the prolonged use of this immunosuppressive drug is limited by the appearance of severe adverse effects, and new MTX-derived compounds have been developed. PIX was synthesized to reduce anthracycline-related cardiotoxicity without compromising antitumor efficacy, and it has been evaluated in the rat EAE model (Cavaletti et al., 2004; Mazzanti et al., 2005), showing amelioration of the disease manifestations, and long-lasting effect on lymphocyte subpopulations and APC. The observed effects were dose-dependent, and no signs of cardiotoxicity were observed. We reported the efficacy of the same total dose of PIX (16.24 mg/kg q7dx3, 1/4 of the $\mathrm{LD}_{10}$, with preventive and therapeutic protocols) in EAMG, the animal model of MG, showing improvement of EAMG conditions and modulation of disease-related immunological parameters, without cardiotoxicity (Ubiali et al., 2008).

In order to better characterize PIX immunosuppressive properties, we investigated whether a reduced drug dosage in combination with modified schedule of treatments (thus lowering the drug cumulative load) were still able to ameliorate EAMG. We initially assessed whether an alternate-week treatment (PIX $16.24 \mathrm{mg} / \mathrm{kg}, \mathrm{q} 14 \mathrm{dx} 3, \mathrm{~T} 1$ protocol) and a half-dosage weekly treatment (PIX $8.12 \mathrm{mg} / \mathrm{kg}$, q7dx6, T2 protocol) could be as efficient as the previously published weekly treatment (PIX $16.24 \mathrm{mg} / \mathrm{kg}$, q7dx3 (Ubiali et al., 2008)); our new results showed that the improved protocols ameliorated EAMG clinical symptoms, and these were associated with reduction of pathogenic anti self AChR antibodies and AChR-specific T helper proliferation. We also observed an even improved effect of the T2 protocol on EAMG, due to a more favorable PIX pharmacokinetic profile, allowing the achievement of a systemic steady-state level of the drug, estimated to be greater than $0.2 \mathrm{nM}$ (Fig. 2).

A further lowered PIX dosage, with two different administration schedules (PIX $8.12 \mathrm{mg} / \mathrm{kg}, \mathrm{q} 14 \mathrm{dx} 3$, T3 protocol and PIX $4.06 \times$ $6 \mathrm{mg} / \mathrm{kg}$, q7dx6, T4 protocol), was also evaluated; however, despite the demonstration of a significant inhibition of AChR-specific T helper proliferation, reduction of the number of LNCs and modification of selected cytokine expression levels, neither protocols efficiently modulated EAMG symptoms. PIX bioavailability assay indicated a $60 \mathrm{pM}$ drug level in the serum $24 \mathrm{~h}$ after administration (PIX $4.06 \mathrm{mg} / \mathrm{kg}$ ), a level comparable with the IC50 for TAChR (25 pM) and R97-116 (63 pM) LNC responses from antigen-primed animals; instead, at 7 days the PIX serum levels dropped to 10 pM, below the IC50 values. Interestingly, PIX bioavailability in serum, after its administration at $8.12 \mathrm{mg} / \mathrm{kg}$, showed a relatively stable level (300 pM and $200 \mathrm{pM}$, after $24 \mathrm{~h}$ and 7 days, respectively), and this may account for the effect of PIX protocol T2 but not T4. PIX levels in the serum of animals treated with PIX T3 and T4 protocols, are able to suppress LNC 
proliferations, and were not cytotoxic for $\mathrm{OX} 33^{+} \mathrm{B}$ cells, as demonstrated by the modest reduction (less than $5-8 \%$ ) in cell viability.

Notably, our data highlighted that even one single low dose of PIX was sufficient to reduce the number of viable LNCs and to block immunocompetent cell proliferation; indeed, the amount of PIX in serum within $24 \mathrm{~h}$ from administration led to an efficient $\mathrm{T}$ cell suppression. It should be noted that we observed PIX mediated-suppression only in an activated immune system: PIX treatment $(16.24 \mathrm{mg} / \mathrm{kg} \times 1)$ in
A

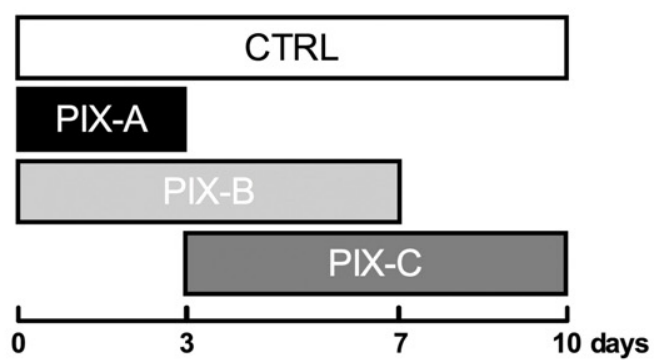

C
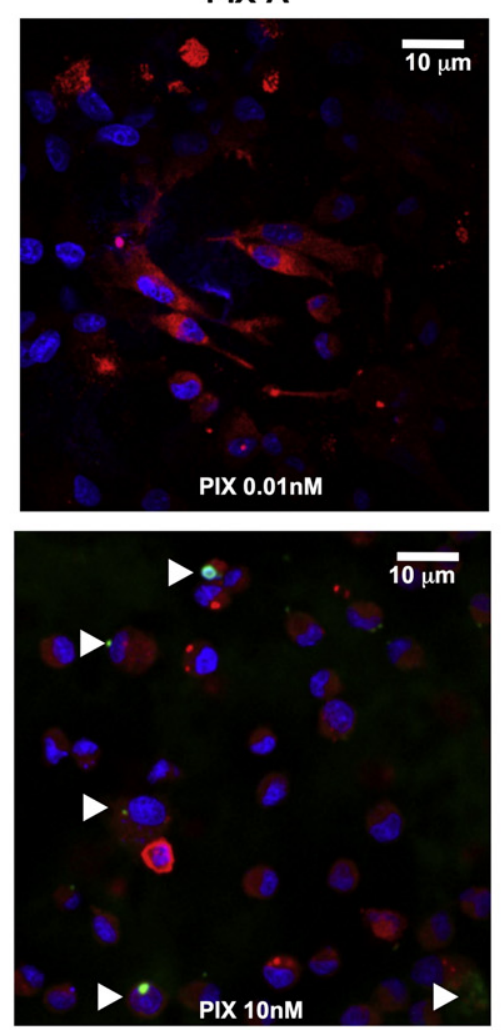

D

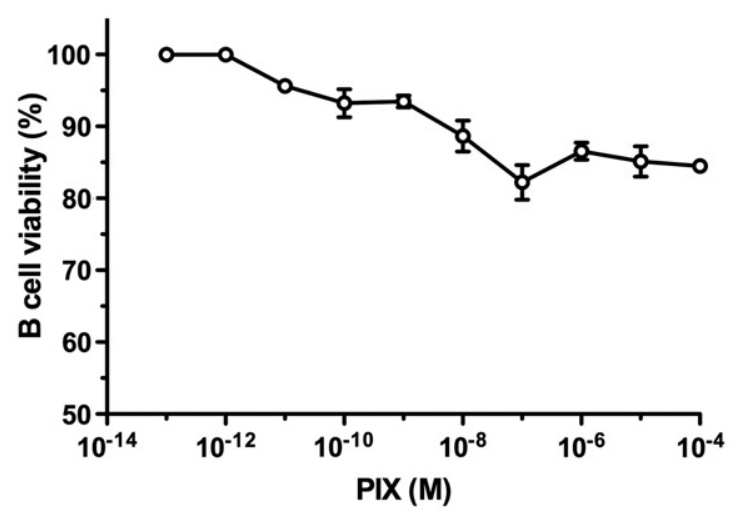

B

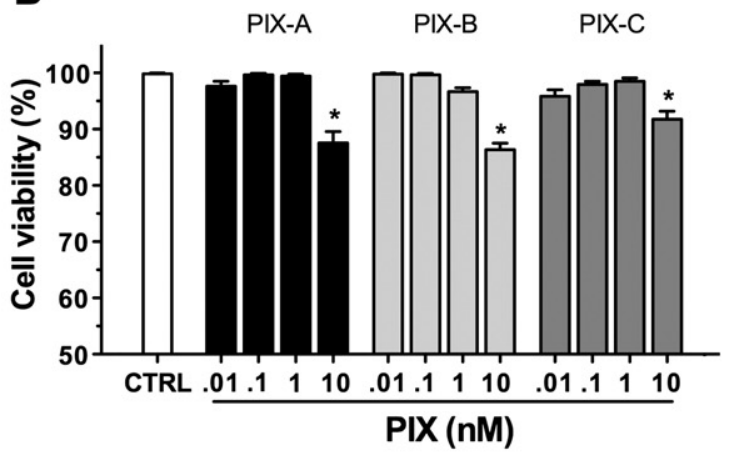

PIX-B
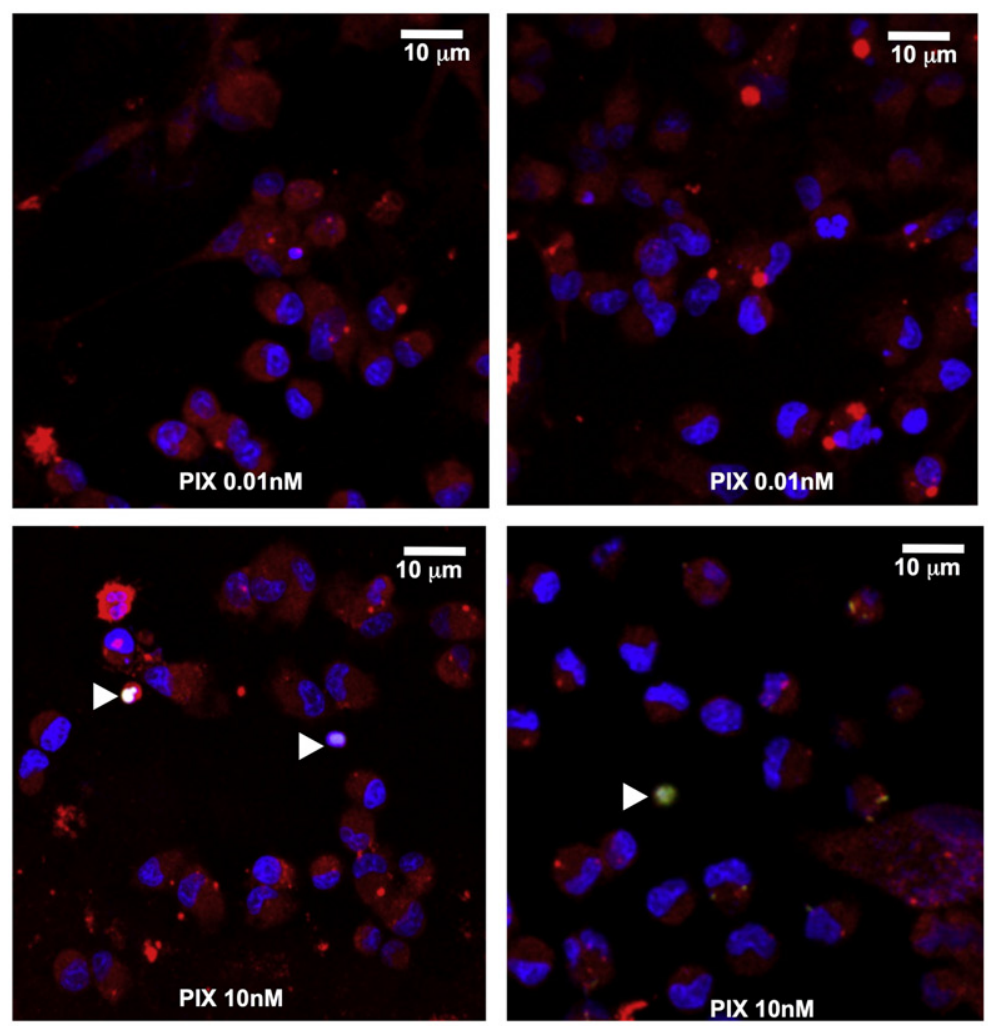

E

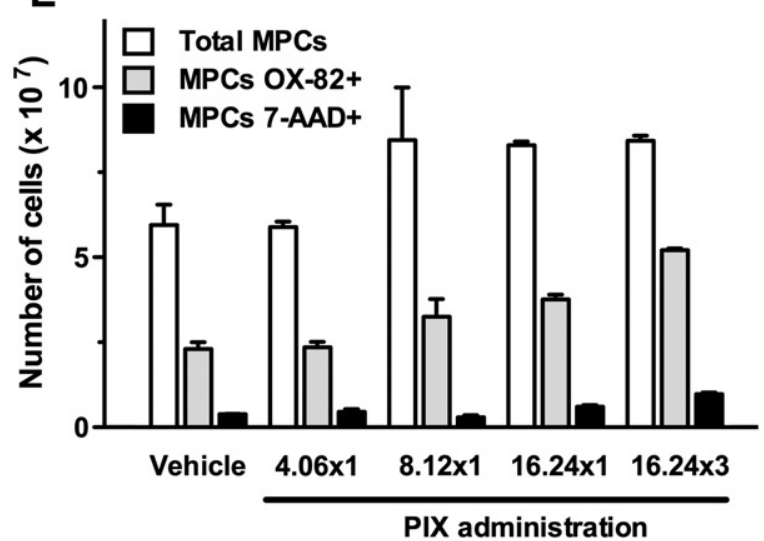


naïve rats (HD/PIX) did not induce any alteration in the lymphoid cell compartment, differently from what we observed in TAChR-immunized animals; this may suggest that PIX does not interfere with the population of naïve resting $\mathrm{T}$ cells, present in not inflamed LNs, but does interfere with proliferating (antigen-activated) $\mathrm{CD}^{+}{ }^{+}$effector T cells.

The calculated PIX IC50 values seem to be specific with regard to the different cell subpopulations analyzed, with the lowest IC50 for homogeneous cultures of antigen-specific $T$ cell lines, and with increasing values if heterogeneous cell populations, such as LNCs and SPNCs isolated from AChR-primed rats, were studied. SPNCs from not immunized (naïve) rats, and PBMCs from healthy human donors, were the most resistant to PIX cytotoxicity. This observation might be of particular relevance, in light of the possible use of PIX for the treatment of autoimmune disorders, as the therapy could be tapered to the appropriate low PIX dosage able to block only actively proliferating T cells. This in turn could be even more relevant if evaluated in the context of combination therapies, based on an initial short course of cytotoxic drugs able to induce antigen specific immunosuppression, followed by a conventional immunomodulation regimen with first-line drugs (induction-maintenance approach) (Conway and Cohen, 2010).

Our study has also demonstrated the feasibility of assessing in vitro the bioavailability of PIX in the serum; we are confident that this bioassay could be rapidly translated in the clinic, being a useful biomarker to carefully monitor the drug level in patients during PIX treatment.

Furthermore, we showed that the low PIX doses, cytotoxic to effector T cells, did not induce B cell death, did not show myelotoxic effects in vivo and did not alter the differentiation of bone marrow MPCs in iDCs in vitro; hence low dose-PIX treatment has a specific effect on actively proliferating effector $\mathrm{T}$ cells, without inducing cytotoxicity on other immune cell compartments. Our treatments showed a good pharmacokinetic profile and were able to ameliorate ongoing EAMG, with an administration schedule of a weekly single dose.

The response of MG to immunosuppression can be variable from patient to patient, and prolonged unresponsiveness can be frequently observed. Treatment-resistant myasthenia can be a real challenge for the clinician, particularly in patients with bulbar impairment. In this regard, the availability of new drugs is awaited.

Recently discovered drugs, such as the reversible inhibitor of inosine monophosphate dehydrogenase inhibitor mycophenolate mofetil (MMF), and the proteasome inhibitor Bortezomib (BZ) both FDA approved for allograft rejection and cancer treatments have been investigated in EAMG. Indeed, MMF proved to be an effective immunosuppressive drug in EAMG, blocking proliferation of $\mathrm{T}$ and $B$ cells, but affecting also DC maturation and antigen presentation (Janssen et al., 2008). MMF is also currently prescribed to MG patients either alone or in association with prednisone (Hehir et al., 2010). Differently from MMF, BZ affects proteasome complex, thus blocking the NF-kB pathway and inducing apoptosis. BZ is, to date, the only drug able to efficiently inhibit terminally differentiated active plasma cells, thus being efficient in plasma cell mediated diseases such as mantle cell lymphoma and multiple myeloma, and therefore these preliminary results may suggest the rationale for their potential investigation in MG (Gomez et al., 2012). However, side effects, such as peripheral neuropathy, might be an issue in case of long-term treatment with BZ. In this respect, PIX may be of interest, either alone or in combination with other immunosuppressant to target both $\mathrm{T}$ and $\mathrm{B}$ cell counterparts of the disease. Therefore, our data provide the rationale for the proposal of clinical studies on PIX in MG to assess primarily its tolerability, and then its clinical efficacy as immunosuppressive compound in a $\mathrm{T}$ cell driven-B cell mediated disease.

\section{Acknowledgments}

The authors declare that no conflict of interest exists.

The authors are grateful to Drs. Jack Singer and Kris Kanellopoulos at Cell Therapeutics Inc. (Seattle, US) for providing Pixantrone and giving support with the investigational drug.

This work was supported in part by European Commission (FIGHT-MG project, HEALTH-F2-2010-242210), CARIPLO Foundation (project number 2009.32550), and Associazione Italiana Miastenia e Malattie Immunodegenerative Amici del Besta-Onlus.

\section{Appendix A. Supplementary data}

Supplementary data to this article can be found online at http:// dx.doi.org/10.1016/j.jneuroim.2013.02.021.

\section{References}

Aharonov, A., Tarrab-Hazdai, R., Silman, I., Fuchs, S., 1977. Immunochemical studies on acetylcholine receptor from Torpedo californica. Immunochemistry 14, 129-137.

Baggi, F., Annoni, A., Ubiali, F., Milani, M., Longhi, R., Scaioli, W., Cornelio, F., Mantegazza, R., Antozzi, C., 2004. Breakdown of tolerance to a self-peptide of acetylcholine receptor alpha-subunit induces experimental myasthenia gravis in rats. J. Immunol. 172, 2697-2703.

Baggi, F., Antozzi, C., Toscani, C., Cordiglieri, C., 2012. Acetylcholine receptor-induced experimental myasthenia gravis: what have we learned from animal models after three decades? Arch. Immunol. Ther. Exp. (Warsz.) 60, 19-30.

Cavalcante, P., Bernasconi, P., Mantegazza, R., 2012. Autoimmune mechanisms in myasthenia gravis. Curr. Opin. Neurol. 25, 621-629.

Cavaletti, G., Cavalletti, E., Crippa, L., Di Luccio, E., Oggioni, N., Mazzanti, B., Biagioli, T. Sala, F., Sala, V., Frigo, M., Rota, S., Tagliabue, E., Stanzani, L., Galbiati, S., Rigolio, R., Zoia, C., Tredici, G., Perseghin, P., Dassi, M., Riccio, P., Lolli, F., 2004. Pixantrone (BBR2778) reduces the severity of experimental allergic encephalomyelitis. J. Neuroimmunol. 151, 55-65.

Christadoss, P., Poussin, M., Deng, C., 2000. Animal models of myasthenia gravis. Clin. Immunol. 94, 75-87.

Cohen, B.A., Mikol, D.D., 2004. Mitoxantrone treatment of multiple sclerosis: safety considerations. Neurology 63, S28-S32.

Conti-Fine, B.M., Milani, M., Kaminski, H.J., 2006. Myasthenia gravis: past, present, and future. J. Clin. Invest. 116, 2843-2854

Conway, D., Cohen, J.A., 2010. Combination therapy in multiple sclerosis. Lancet Neurol. 9, 299-308.

Cordiglieri, C., Odoardi, F., Zhang, B., Nebel, M., Kawakami, N., Klinkert, W.E., Lodygin, D., Luhder, F, Breunig. E Schild, D. Ulaganathan, V.K. Dornmair, K, Dammermann, W. Potter, B.V., Guse, A.H., Flugel, A., 2010. Nicotinic acid adenine dinucleotide phosphatemediated calcium signalling in effector T cells regulates autoimmunity of the central nervous system. Brain 133, 1930-1943.

De Isabella, P., Palumbo, M., Sissi, C., Capranico, G., Carenini, N., Menta, E., Oliva, A., Spinelli, S., Krapcho, A.P., Giuliani, F.C., et al., 1995. Topoisomerase II DNA cleavage stimulation, DNA binding activity, cytotoxicity, and physico-chemical properties of 2-aza- and 2-aza-oxide-anthracenedione derivatives. Mol. Pharmacol. 48, 30-38.

Fambrough, D.M., Drachman, D.B., Satyamurti, S., 1973. Neuromuscular junction in myasthenia gravis: decreased acetylcholine receptors. Science 182, 293-295.

Ghalie, R.G., Edan, G., Laurent, M., Mauch, E., Eisenman, S., Hartung, H.P., Gonsette, R.E. Butine, M.D., Goodkin, D.E., 2002. Cardiac adverse effects associated with mitoxantrone (Novantrone) therapy in patients with MS. Neurology 59, 909-913.

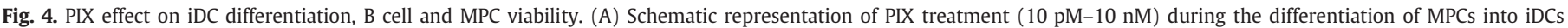

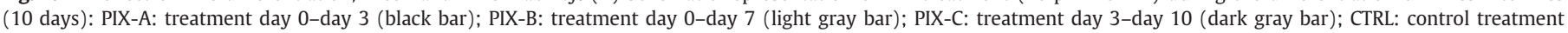

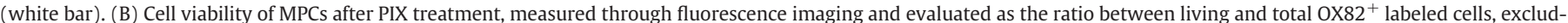

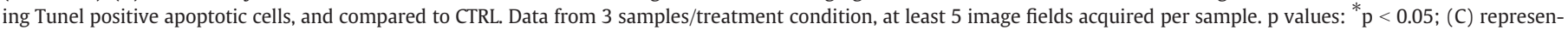

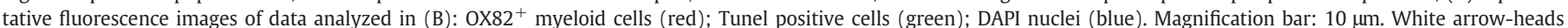

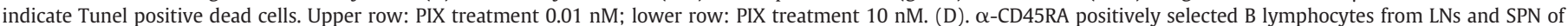

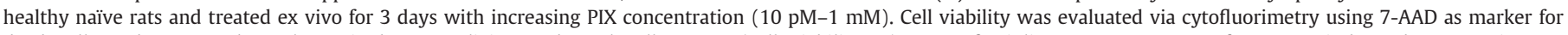

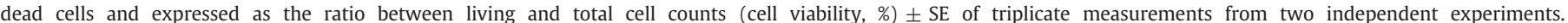

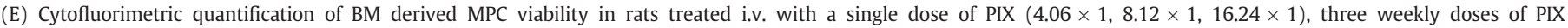

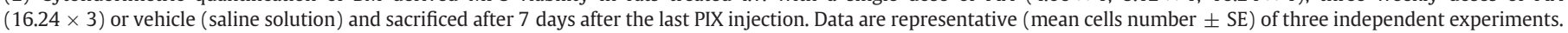
Total MPCs (white bars), OX82 ${ }^{+}$myeloid cells (gray bars) and 7-AAD ${ }^{+}$dead cells (black bars) are analyzed via cytofluorimetry. 
Gomez, A.M., Willcox, N., Molenaar, P.C., Buurman, W., Martinez-Martinez, P., De Baets, M.H., Losen, M., 2012. Targeting plasma cells with proteasome inhibitors: possible roles in treating myasthenia gravis? Ann. N. Y. Acad. Sci. 1274, 48-59.

Gonsette, R.E., 2007. Compared benefit of approved and experimental immunosuppressive therapeutic approaches in multiple sclerosis. Expert. Opin. Pharmacother. 8, 1103-1116.

Hehir, M.K., Burns, T.M., Alpers, J., Conaway, M.R., Sawa, M., Sanders, D.B., 2010. Mycophenolate mofetil in AChR-antibody-positive myasthenia gravis: outcomes in 102 patients. Muscle Nerve 41, 593-598.

Heinemann, S., Bevan, S., Kullberg, R., Lindstrom, J., Rice, J., 1977. Modulation of acetylcholine receptor by antibody against the receptor. Proc. Natl. Acad. Sci. U. S. A. 74, 3090-3094.

Im, S.H., Barchan, D., Maiti, P.K., Fuchs, S., Souroujon, M.C., 2001. Blockade of CD40 ligand suppresses chronic experimental myasthenia gravis by down-regulation of Th1 differentiation and up-regulation of CTLA-4. J. Immunol. 166, 6893-6898.

Janssen, S.P., Phernambucq, M., Martinez-Martinez, P., De Baets, M.H., Losen, M., 2008. Immunosuppression of experimental autoimmune myasthenia gravis by mycophenolate mofetil. J. Neuroimmunol. 201-202, 111-120.

Kao, I., Drachman, D.B., 1977. Myasthenic immunoglobulin accelerates acetylcholine receptor degradation. Science 196, 527-529.

Karachunski, P.I., Ostlie, N.S., Monfardini, C., Conti-Fine, B.M., 2000. Absence of IFNgamma or IL-12 has different effects on experimental myasthenia gravis in C57BL/6 mice. J. Immunol. 164, 5236-5244.

Kumar, V., Kaminski, H.J., 2011. Treatment of myasthenia gravis. Curr. Neurol. Neurosci. Rep. 11, 89-96.

Lindstrom, J., Einarson, B., Tzartos, S., 1981. Production and assay of antibodies to acetylcholine receptors. Methods Enzymol. 74 (Pt C), 432-460.

Mantegazza, R., Bonanno, S., Camera, G., Antozzi, C., 2011. Current and emerging therapies for the treatment of myasthenia gravis. Neuropsychiatr. Dis. Treat 7, 151-160.

Martinelli, V., Cocco, E., Capra, R., Salemi, G., Gallo, P., Capobianco, M., Pesci, I., Ghezzi, A., Pozzilli, C., Lugaresi, A., Bellantonio, P., Amato, M.P., Grimaldi, L.M., Trojano, M.,
Mancardi, G.L., Bergamaschi, R., Gasperini, C., Rodegher, M., Straffi, L., Ponzio, M. Comi, G., Italian Mitoxantrone, G., 2011. Acute myeloid leukemia in Italian patients with multiple sclerosis treated with mitoxantrone. Neurology 77, 1887-1895.

Mazzanti, B., Biagioli, T., Aldinucci, A., Cavaletti, G., Cavalletti, E., Oggioni, N., Frigo, M., Rota, S., Tagliabue, E., Ballerini, C., Massacesi, L., Riccio, P., Lolli, F., 2005. Effects of Pixantrone on immune-cell function in the course of acute rat experimental allergic encephalomyelitis. J. Neuroimmunol. 168, 111-117.

Nessi, V, Nava, S, Ruocco, C., Toscani, C, Mantegazza, R, Antozzi, C, Baggi, F, 2010. Naturally occurring CD4 $+\mathrm{CD} 25+$ regulatory $T$ cells prevent but do not improve experimental myasthenia gravis. J. Immunol. 185, 5656-5667.

Pettengell, R., Coiffier, B., Narayanan, G., de Mendoza, F.H., Digumarti, R., Gomez, H. Zinzani, P.L., Schiller, G., Rizzieri, D., Boland, G., Cernohous, P., Wang, L., Kuepfer, C., Gorbatchevsky, I., Singer, J.W., 2012. Pixantrone dimaleate versus other chemotherapeutic agents as a single-agent salvage treatment in patients with relapsed or refractory aggressive non-Hodgkin lymphoma: a phase 3, multicentre, open-label, randomised trial. Lancet Oncol. 13, 696-706.

Romagnani, S., 1997. The Th1/Th2 paradigm. Immunol. Today 18, 263-266.

Souroujon, M.C., Brenner, T., Fuchs, S., 2010. Development of novel therapies for MG: studies in animal models. Autoimmunity $43,446-460$.

Srokowski, T.P., Liebmann, J.E., Modiano, M.R., Cohen, G.I., Pro, B., Romaguera, J.E. Kuepfer, C., Singer, J.W., Fayad, L.E., 2011. Pixantrone dimaleate in combination with fludarabine, dexamethasone, and rituximab in patients with relapsed or refractory indolent non-Hodgkin lymphoma: phase 1 study with a dose-expansion cohort. Cancer 117, 5067-5073.

Ubiali, F., Nava, S., Nessi, V., Longhi, R., Pezzoni, G., Capobianco, R., Mantegazza, R., Antozzi, C., Baggi, F., 2008. Pixantrone (BBR2778) reduces the severity of experimental autoimmune myasthenia gravis in Lewis rats. J. Immunol. 180, 2696-2703.

Weigle, W.O., Romball, C.G., 1997. CD4 + T-cell subsets and cytokines involved in peripheral tolerance. Immunol. Today 18, 533-538. 